\title{
Learning by Doing: A Simulation for Teaching How Congress Works
}

Eric C. Sands, Berry College

Allison Shelton, University of Georgia

ABSTRACT Teachers of political science have increasingly recognized the utility of classroom simulations to provide students with an active-learning experience to enhance learning outcomes. Our article builds on this growing trend by proposing a congressional simulation to help students understand the complexities and nuances of the lawmaking process. Specifically, the simulation aids students in identifying the deliberative aspects of congressional policymaking, appreciating the complicated process involved in a bill becoming a law, understanding the multifaceted ways in which self-interest guides the decisions of congressional actors, and challenging student cynicism about Congress as an institution.

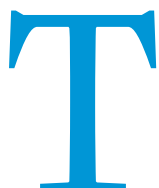

he use of simulations first became popular in the education community in the 1960 s as educational psychologists recognized the innate ability of student-centered activities to enhance both the cognitive and affective (relating to value judgments) absorption of knowledge (Boocok and Schild 1968; Dewey 1966; Holt 1967; Smith and Smith 1966.) Over the next 40 years, this recognition evolved into a general acceptance of interactive activities as more effective teaching methodologies than standard didactic instruction (Bandura 1977; Greenblat 1973; Greenblat and Duke 1975; Heitzmann 1974; Kolb 1984; Maxson 1974).

Scholars grounded this acceptance in an understanding that it was through the active engagement, processing, and constructing of material that students learned, not through the mere passive reception of information typical of a lecture hall (Bolles 1988; Klionsky 2001). This conceptualization of learning extended even beyond the study of education pedagogy, as it was adopted by brain research specialists who began studying "whole brain learning," or the concept of teaching to the multiple intelligences of the brain (Gorovitz 1982).

As a result of this extensive scholarship, the use of simulations has become an established practice in classrooms pursuing higherorder cognitive and affective objectives. In fact, the effectiveness of simulations has been so widely established that they have been adopted in academic, business, and military settings around the world (Assa 1982; Crookall 1995; Rohn 1986).

Eric C. Sands is assistant professor of government and international studies at Berry College. He is the author of American Public Philosophy and the Mystery of Lincolnism as well as other scholarly articles on American political thought. He can be reached at esands@berry.edu.

Allison M. Shelton is a graduate student in political science and international affairs at the University of Georgia's School of Public and International Affairs. Her areas of research include security studies, alliance formation, and American foreign policy. She can be reached at ashelton@uga.edu.
To be sure, political scientists have not ignored the value that simulations play in teaching students about politics. It has long been recognized (Walcott 1980; Dodge 1983) that simulations are a valuable tool in helping students to understand the complex dynamics of institutions and political systems, and this lesson has been applied to many areas of the discipline, including comparative politics (Shellman 2001; Galatas 2006; Kaarbo and Lantis 1997), international relations (Jefferson 1999; Winham 1991; Dougherty 2003), and American politics (Hensley 1993; Thomas 2002; Endersby and Webber 1995; Ciliotta-Rubery and Levy 2000). In short, it has become increasingly accepted by teachers of political science that simulations "have the power to recreate complex, dynamic political processes in the classroom, allowing students to examine the motivations, behavioral constraints, resources and interactions among institutional actors ... after a simulation, participants have a deeper understanding of institutions, their successes and failures" (Smith and Boyer 1996, 690).

There is one particular area of teaching political science that continues to vex even the best of instructors-Congress. Lee Hamilton, a former member of the House of Representatives and a current member of the president's Homeland Security Advisory Council, explains the problem this way: "the lack of public understanding about the institution is huge ... [and this ignorance] increases the public's suspicions and cynicism about the Congress, weakens the relationship between voters and their representatives, makes it harder for public officials to govern, and prevents our representative democracy from working the way it should" (Hamilton 2000, 757). To overcome this lack of knowledge about Congress, Hamilton recommends the use of teaching and instructional techniques that can help students to appreciate better the complexity of the legislative process, thereby helping reduce voter cynicism and strengthen the bonds between members of Congress and their constituents. Specifically, Hamilton calls 
for political scientists to do a better job getting their students to understand:

- That the "legislative process is dynamic and complex ... [explanations of the bill-making process need to emphasize] the hard work, the excitement, the obstacles to overcome, the political pressures, the defeats suffered, and the victories achieved to enact legislation" (Hamilton 2000, 760).

- That legislation is a "complicated and untidy process" that involves many competing and conflicting interests (Hamilton 2000, 760).

- That legislation is a deliberative process and that representative democracy, while certainly having its faults, largely works (Hamilton 2000, 760, 763).

- That "members of Congress behave better than people think" and that individual self-interest, through institutional design, often serves the common good (Hamilton 2000, 761).

Yet it is precisely these kinds of lessons about Congress that are difficult to get across to students in courses employing traditional lecture-based or didactic teaching methods. In many cases, students cling to negative stereotypes and prejudices about Congress, which seems to require herculean efforts by teachers in helping students think about the institution in a critical and informed way. Perhaps, however, the problem is not so much with the message given to students but with the medium by which it is presented. The use of a well-designed congressional simulation can be a valuable tool in helping students examine, justify, or even revise their opinions about Congress. To that end, we propose the following congressional simulation that successfully enables students to achieve the higher-order analysis described by Hamilton.

\section{LEARNING OBJECTIVES}

Whereas a good lecturer can narrate a compelling account of the complex nature of Congress, the great value of a simulation is that it fundamentally shifts student learning to the next level. For unless students are able to actively engage the concepts being taught in a constructive way, they will rarely learn the content material affectively, or in a way that educates or even changes the individual's value judgments of the content. Utilizing a simulation takes students' understanding of the material from simple comprehension to appreciation, allowing them to draw normative conclusions and implications about Congress as an institution. It should be noted, however, that the objective of the simulation is not to promote an unequivocally positive opinion of Congress; rather, the goal of student participation in the simulation is to promote a critical examination of student knowledge and assessment about Congress as an institution through an experiential learning exercise that is nearly impossible to replicate in a lecture hall.

There are four primary student-learning objectives for the simulation model:

1. The student will develop a better appreciation for the complicated process by which a bill becomes law.

2. The student will gain insight into Congress as a deliberative institution, and will identify the parts of the legislative process where deliberation takes place.

3. The student will recognize that Congress is an institution that creates motivations of competing self-interest, yet its mem- bers, while pursuing their own interests, often end up advancing the common good.

4. The student will examine any initial skepticism and criticism regarding Congress by analyzing those attitudes through the lens of the simulation experience.

\section{SIMULATION CONSTRUCTION}

The congressional simulation model is designed to require its student participants to simulate, in a reasonably accurate way, the structures and procedures of Congress as they cooperatively work to draft a bill on a predetermined legislative topic. Throughout the simulation, participants deal with and must often decide between competing motivations of self-interest. The proctoring professor maintains a record of votes accumulated by each participant toward the goal of reelection at the end of the simulation. To ensure a high level of student engagement, a portion of the final grade hinges on the passage (or blockage) of a bill and whether or not an individual has garnered enough votes throughout the simulation to warrant reelection. The emphasis on reelection is not intended to make representatives in Congress appear purely selfish, but to reinforce the fact that election is a necessary precursor for success in Congress.

The congressional-simulation logistics and procedures presented here were created with the idea of ensuring enough flexibility in order to adapt to different classroom environments. It should be clear that the effective implementation of this simulation will require adjustments in order to fit with particular groups of students. For these reasons, the simulation is intended to be malleable and adaptable in its procedures. However, the strategies used to expose participants to the competing self-interested motivations of members of Congress and the deliberative process should not be altered, for these factors are ultimately what produce the desired student-learning outcomes.

The congressional simulation was tested in upper-division courses on Congress, each time involving approximately 25 students, though it could certainly work with greater or fewer numbers. The simulation was carried out over a two-week period, and while this length is flexible, it is important to note that the shorter the simulation period, the more abbreviated the legislative process of the simulation must become. Moreover, the simulation does not require student participants to learn Robert's Rules of Order since time constraints make it nearly impossible to require participants to master parliamentary rules. As such, during formal debate, the proctoring professor serves as both the non-voting Speaker of the House and president pro tempore of the Senate to ensure that debate proceeds in an orderly manner according to the rules established by the party leadership early in the simulation.

Throughout the simulation, the proctoring professor might also be required to fill other roles, such as a representative of interest and lobbying groups or the executive branch, which solicit support or opposition to the bill by offering reelection votes to student participants. These roles can be filled by other faculty members if such resources are available. Moreover, there are six leadership roles filled by students in the simulation. In the House of Representatives, four students were elected by their peers early in the simulation to serve as the majority leader, the majority whip, the minority leader, and the minority whip. In the Senate, two students were similarly elected to serve as the majority leader and the minority leader. All other student participants served as representatives or senators. ${ }^{1}$ Students who participated in this 
study also had the opportunity to solicit congressional aides from students in lower-level American government classes in exchange for extra credit; it is recognized that not every situation would afford this same opportunity, and it is certainly not required for a successful simulation.

The proctoring professor must also maintain a careful record of all contracted vote relationships made among participants as well as those individuals serving as interest groups. This calculation of votes is a critical component of the simulation model, for it is through this rational-actor component that students affectively learn about the competing motives of self-interest experienced by representatives of Congress. While it must be acknowledged that there may be fear of the grade based on this component of the simulation being perceived as too subjective, it is important to understand that the portion of the student's final grade dependent on the reelection votes should be only enough to promote high engagement and interest, not make or break the student's final grade. A sample is presented in the appendix along with examples of how such votes might be distributed in a substantively relevant manner:

When choosing the topic for the simulation, we recommend that the proctoring professor tailor the topic to the culture and students of the school in question; indeed for this congressional simulation to be successful, a great deal of consideration must be given to the topic. Questions to answer during this process might include: How conceptually accessible is the topic? Has this topic already been resolved by the real U.S. Congress? Is the topic interesting enough to engage students, but not so divisive as to cause significant conflict? Is the topic appropriate to the time constraints of the simulation? Is there a reasonable expectation that students accurately representing the views of their assigned party and states would disagree on the topic? We required student participants to draft a bill addressing oil drilling in the ANWR Alaskan wildlife reserve. Other potential topics might include a federal ban on assault rifles, a federal ban on flag burning, a federal bill retracting or expanding the No Child Left Behind Act (NCLB), a federal ban on trans fat, and a federal bill supporting public-school choice and/or school vouchers.

\section{SIMULATION EXECUTION}

In executing the simulation, we prepared a procedural outline, which is detailed below. The outline articulates the pre-simulation duties of the proctoring professor as well as the substantive progress of the simulation:

\section{Pre-simulation duties of the proctoring professor:}

- Provide general overview of process of bill becoming law

- Randomly assign student participants to states and parties

- Establish the congressional breakdown to roughly model the current partisan distribution of power in the U.S. Congress

- Prepare vote-distribution chart (see appendix)

- Establish grade weight of simulation

- Extend extra credit to students in lower-level government classes who agree to serve as congressional aides (optional)

- Pick topic for bill

Week One (commencement of student involvement):

- Participants vote for party leadership

- Introduction of the bills in both houses

- Assignment of bill to committees in both houses
- Committee work on the bill in both houses

- Both houses vote the bill to the floor for formal debate

\section{Week Two:}

- Formal floor debate on the bill in both houses

- First vote takes place in both houses

- Formation and work of Conference Committee outside of class

- Resubmission of the bill to the floor of both houses

- Formal floor debate on the bill in both houses

- Second vote takes place in both houses

\section{Week Three:}

- Classroom review and analysis of simulation

\section{ASSESSMENT OF STUDENT-LEARNING OBJECTIVES}

In order to fully assess student mastery of learning objectives, we utilized multiple measurements. A relatively small portion of the final student grade $(25 \%)$ actually depended on the total number of reelection votes they garnered throughout the simulation. Because the final calculation of reelection was based on a bell curve, students needed to finish the simulation having earned as many votes as possible to ensure their reelection and success in this assessment measure. Another component of the final student grade $(20 \%)$ was based on an individual brief summary of the final bill and an analysis of how well the bill addressed the policy issue from the perspective of the best interests of the representative and the best interest of the country, as perceived by the individual student. This assessment was intended to help reinforce for students the complex nature of congressional representation perspectives-the sometimes contrasting interests of a representative's constituency (delegate) and what they as individuals feel is the best for the common good (trustee). When gauging how well student participants mastered the first learning objective, "the student will gain a greater understanding for the process by which a bill becomes law" in the U.S. Congress, we measured student success through cumulative exams (35\%). For the remaining three student-learning objectives, we utilized essay assessments $(20 \%)$ in which students wrote a three- to five-page essay reflecting on several question prompts comparing pre- and post-simulation opinions about Congress: What were your opinions about Congress as an institution prior to the simulation? Were these opinions validated or challenged by the simulation? In what way? Similarly, did the simulation have any impact on your pre-simulation attitudes about congressional representatives? If so, in what way? What aspects of the U.S. Congress were unfamiliar to you or surprised you as the simulation proceeded? What did you feel was good about the simulation? What did you feel could have been done better? ${ }^{2}$

\section{ASSESSMENT}

The student feedback from the exams and essays fell into several categories that matched the learning objectives. The overall response to the simulation was very positive. The students (97\%) almost unanimously enjoyed the active-learning approach and thought (94\%) that it had contributed significantly to their understanding of Congress and the lawmaking process. Typical was the comment of one student who said, "I guess I never really appreciated how complex and cumbersome the legislative process is. 
Yet I now realize the complexity is necessary to make sure that everyone has a chance to make their views and opinions heard and everyone's interests have a chance of being represented." Another student echoed another common theme in saying, "There are just so many things going on all at once ... it's amazing that anything gets done at all. But I guess the process wasn't designed to be fast, but to protect our rights." In short, it was apparent from the students' feedback that the simulation was successful in helping students appreciate the many difficulties members of Congress face while trying to craft and pass legislation. It was also clear that students understood that this complexity was an essential component in safeguarding people's rights and liberties.

The simulation significantly challenged many students' perceptions about the amount of deliberation that actually takes place in Congress. As one student explained his pre-simulation attitude, "Frankly, I didn't believe that our representatives deliberated at all. I only saw them as trying to get power and posturing and demagoguing for the media." It became clear, however, that the simulation softened these perceptions. More than $85 \%$ of the students said that the simulation helped them to see that deliberation takes place in several parts of the legislative process, especially in congressional committees. Indeed, the committees, which students had shown little interest in when covered during class lectures, were seen as a saving grace for deliberation in Congress. Students remarked that the committees "are where the real work in Congress gets done" and "represent the promise of democratic politics." In short, the simulation clarified for students that "while there is certainly a lot of self-interest involved, it's not the only thing ... people really do seem to care about making good laws by working with others."

As the previous student's statement makes clear, the simulation did not disabuse students of the belief that a lot of what motivates members of Congress is self-interest, not that it should have. What it did accomplish, however, was to cast self-interest in a new light. More than $80 \%$ of the students said that after the simulation, they came away with a very different opinion about the role of self-interest in the policymaking process. While the students allowed that most members of Congress are concerned with reelection, among other things, they reflected that the pursuit of self-interest often coincided the pursuit of the common good. As one student put it, "self-interest is what made me pay attention to my constituents back home and the mood of the country, and it is also why I cared about encroachments on legislative power by the other branches. It was hard with all of these different interests-constituents, parties, issue groups-all tugging me in different directions." Thus "self-interest in Congress, while sometimes a bad thing, is also what keeps people in Congress focused on the big picture." The goal, then, is not "to eliminate self-interest, but to use that self-interest to keep [members of Congress] pointed in the right direction."

Finally, many students (76\%) also came away from the simulation with a much higher opinion of individual members of Congress. When asked how they would rate their own ethical behavior and the behavior of other participants of the simulation, students generally gave themselves and others high marks for ethical conduct. As one student explained, "sure a lot of people were acting in ways to maximize their chances of getting reelected, but they were also worried about doing right by their districts, their states, their parties, and the country. I don't envy real [members of Congress], what they do is hard." Another student related that "for people on the outside, it looks like the members of Congress are all corrupt. But I see now that this is too simplistic, and really not fair." While the students certainly did not see members of Congress as angels, and many still insisted that "some" members are corrupt, they also said that Congress, as a whole, "involves a lot of decent people trying to do the best they can in an almost impossible job. There is a lot to admire about Congress."

\section{CONCLUSION}

Teaching students about how Congress works continues to be one of the most challenging tasks facing political science professors. Furthermore, creating classroom exercises that can engage and entertain, while simultaneously helping students examine prevailing prejudices and cynicism about the institution and members of Congress themselves, is no small feat. Simulations are an effective way of helping instructors to accomplish these tasks. While it is true that simulations like the one discussed here require different sorts of preparation than class lectures, the results are so rewarding that it justifies the additional effort. Students walk away not only with a better understanding of how the institution operates, but they also gain important insight into the motivations and behaviors of members of Congress themselves. Teachers of legislative politics could hardly ask for more.

\section{NOTES}

The authors would like to thank Kirsten Taylor, Hether Scheel, Jacque Smith, and Beth Anne Dunagan for their assistance in preparing this article.

1. The distribution and number of student roles is necessarily dictated by the number of students participating in the simulation.

2. The relatively small class sizes for the simulation (20-25) allowed for extensive debriefing and qualitative feedback about the exercise. Unfortunately, the small class size made the use of a control group impractical.

\section{REFERE N C ES}

Assa, I. 1982. "Management Simulation Games for Education and Research: A Comparative Study of Gaming in the Socialist Countries." Simulation \& Games 13 (4): 379-412.

Bandura, Albert. 1977. Social Learning Theory. Englewood Cliffs, NJ: Prentice-Hall. Bolles, E. 1988. Remembering and Forgetting: Inquiries into the Nature of Memory. New York: Walker.

Boocok, S. S., and E. O. Schild. 1968. Simulation Games in Learning. Beverly Hills: Sage Publications.

Ciliotta-Rubery, Andrea, and Dana Levy. 200o. "Congressional Committee Simulation: An Active Learning Experiment.” PS: Political Science and Politics 33 (4): 847-51.

Crookall, D. 1995. “Simulation/Gaming: A Guide to the Literature.” In Simulation and Gaming Across Disciplines and Cultures: ISAGA at a Watershed, ed. D. Crookall and K. Arai. Thousand Oaks, CA: Sage Publications, 151-77.

Dewey, J. 1966. Lectures in the Philosophy of Education. New York: Random House.

Dodge, Dorothy R. 1983. "Domestic Politics Games and Simulations: An Evaluation." In The Guide to Simulations/Games for Education and Training, ed. Robert Horn and Anne Cleaves. Beverly Hills: Sage Publications, 47-57.

Dougherty, Beth K. 2003. "Byzantine Politics: Using Simulations to Make Sense of the Middle East." PS: Political Science and Politics 36 (2): 239-44.

Endersby, James W., and David M. Webber. 1995. "Iron Triangle Simulation: A Role-Playing Game for Undergraduates in Congress, Interest Groups, and Public Policy Classes." PS: Political Science and Politics 28 (3): 520-23.

Galatas, Steven E. 2006. "A Simulation of the Council of the European Union: Assessment of the Impact on Student Learning." PS: Political Science and Politics 39 (1): 147-52.

Gorovitz, Elizabeth Shey. 1982. "The Creative Brain II: A Revisit with Ned Herrmann." Training and Development Journal (December): 74-88.

Greenblat, C. S. 1973. "Teaching with Simulation Games.” Teaching Sociology October: $62-83$.

Greenblat, C. S., and R. D. Duke. 1975. Gaming-Simulation. New York: John Wiley.

Hamilton, Lee H. 200o. "Ten Things I Wished Political Science Professors Would Teach." PS: Political Science and Politics 33 (4): 757-64. 
Heitzmann, W. R. 1974. Educational Games and Simulations. Washington, D.C.: National Science Teachers Association.

Hensley, Thomas R. 1993. "Come to the Edge: Role Playing Activities in a Constitutional Law Class.” PS: Political Science and Politics 26 (1): 64-68.

Holt, J. 1967. How Children Learn. New York: Pitman.

Jefferson, Kurt. 1999. “The Bosnian War Crimes Trial Simulation: Teaching Students about the Fuzziness of World Politics and International Law." PS: Political Science and Politics 32 (3): 589-92.

Kaarbo, Juliet, and Jeffrey S. Lantis. 1997. "Coalition Theory in Praxis: A Comparative Politics Simulation of the Cabinet Formation Process." PS: Political Science and Politics $30(3): 501-06$.

Klionsky, D. 2001. "Constructing Knowledge in the Lecture Hall." Journal of College Science Teaching 31: 246-51.

Kolb, David Al. 1984. Experiential Learning: Experience as the Source of Learning and Development. Englewood Cliffs, NJ: Prentice-Hall.

Maxson, R. C. 1974. “Simulation: A Method That Can Make a Difference." Education Digest (March): 48-50.
Rohn, W. E. 1986. "The Present State and Future Trends in Management Games for Management Development in Germany." Simulation \& Games 17 (3): 382-92.

Shellman, Stephen. 2001. "Active Learning in Comparative Politics: A Mock German Election and Coalition-Formation Simulation." PS: Political Science and Politics 34 (4): 827-34

Smith, Elizabeth T., and Mark A. Boyer. 1996. "Designing In-Class Simulations." PS: Political Science and Politics 29 (4): 690-94.

Smith, K. U., and M. F. Smith. 1966. Cybernetic Principles of Learning and Educational Design. New York: Holt, Rinehart and Winston, Inc.

Thomas, G. Dale. 2002. "The Isle of Ted Simulation: Teaching Collective Action in International Relations and Organization." PS: Political Science and Politics 34 (3): 555-59.

Walcott, Charles. 1980. Simple Simulations 2. Washington, D.C.: American Political Science Association.

Winham, Gilbert R. 1991. "Simulations for Teaching and Analysis." In International Negotiation, ed. Victor Kremenyuk. San Francisco: Jossey-Bass Publishers, 465-8o.

\section{APPENDIX}

\section{RECORD OF SIMULATION VOTES-SENATE ISSUE: OIL DRILLING IN ANWR}

\begin{tabular}{|c|c|c|c|c|c|c|c|c|}
\hline SOURCES OF VOTES & $\begin{array}{c}\text { MAJORITY } \\
\text { LEADER, } \\
\text { IL (D) }\end{array}$ & $\begin{array}{l}\text { MINORITY } \\
\text { LEADER, } \\
\text { VA (R) }\end{array}$ & $\begin{array}{l}\text { SENATOR, } \\
\text { AK (D) }\end{array}$ & $\begin{array}{l}\text { SENATOR, } \\
\text { WASHINGTON (D) }\end{array}$ & $\begin{array}{l}\text { SENATOR, } \\
\text { S. CAROLINA (D) }\end{array}$ & $\begin{array}{l}\text { SENATOR, } \\
\text { TEXAS (R) }\end{array}$ & $\begin{array}{l}\text { SENATOR, } \\
\text { CALIFORNIA (R) }\end{array}$ & $\begin{array}{l}\text { SENATOR, } \\
\text { MAINE (R) }\end{array}$ \\
\hline Initial Allotment & 10 & 10 & 10 & 10 & 10 & 10 & 10 & 10 \\
\hline Political Party & $+8 /-8$ & $+8 /-8$ & $+8 /-8$ & $+8 /-8$ & $+8 /-8$ & $+8 /-8$ & $+8 /-8$ & $+8 /-8$ \\
\hline Party Leadership & $+3 /-3$ & $+3 /-3$ & N/A & N/A & N/A & N/A & N/A & N/A \\
\hline State Constituents & $+5 /-5$ & $+5 /-5$ & $+8 /-8$ & $+7 /-7$ & $+5 /-5$ & $+7 /-7$ & $+7 /-7$ & $+5 /-5$ \\
\hline Interest Groups & $+5 /-5$ & $+5 /-5$ & $+7 /-7$ & $+4 /-4$ & $+1 /-1$ & $+2 /-2$ & $+2 /-2$ & $+1 /-1$ \\
\hline Executive Branch & $+3 /-3$ & $+3 /-3$ & $+3 /-3$ & $+2 /-2$ & $+1 /-1$ & $+2 /-2$ & $+2 /-2$ & $+1 /-1$ \\
\hline
\end{tabular}

RECORD OF SIMULATION VOTES-HOUSE OF REPRESENTATIVES ISSUE: OIL DRILLING IN ANWR

\begin{tabular}{|c|c|c|c|c|c|c|c|c|}
\hline SOURCES OF VOTES & $\begin{array}{c}\text { SPEAKER } \\
\text { OF THE HOUSE, } \\
\text { IN (D) }\end{array}$ & $\begin{array}{l}\text { MINORITY } \\
\text { LEADER, } \\
\text { PA (R) }\end{array}$ & $\begin{array}{l}\text { REP., } \\
\text { AK (D) }\end{array}$ & $\begin{array}{c}\text { REP., } \\
\text { OREGON (D) }\end{array}$ & $\begin{array}{l}\text { REP., } \\
\text { FLORIDA (D) }\end{array}$ & $\begin{array}{c}\text { REP., } \\
\text { TEXAS (R) }\end{array}$ & $\begin{array}{l}\text { REP., } \\
\text { CALIFORNIA (R) }\end{array}$ & $\begin{array}{c}\text { REP., } \\
\text { S. DAKOTA (R) }\end{array}$ \\
\hline Initial Allotment & 10 & 10 & 10 & 10 & 10 & 10 & 10 & 10 \\
\hline Political Party & $+10 /-10$ & $+10 /-10$ & $+10 /-10$ & $+10 /-10$ & $+10 /-10$ & $+10 /-10$ & $+10 /-10$ & $+10 /-10$ \\
\hline Party Leadership & $+3 /-3$ & $+3 /-3$ & N/A & $\mathrm{N} / \mathrm{A}$ & $N / A$ & $\mathrm{~N} / \mathrm{A}$ & $\mathrm{N} / \mathrm{A}$ & N/A \\
\hline State Constituents & $+7 /-7$ & $+7 /-7$ & $+10 /-10$ & $+9 /-9$ & $+7 /-7$ & $+9 /-9$ & $+9 /-9$ & $+7 /-7$ \\
\hline Interest Groups* & $+3 /-3$ & $+3 /-3$ & $+5 /-5$ & $+2 /-2$ & $+1 /-1$ & $+2 /-2$ & $+2 /-2$ & $+1 /-1$ \\
\hline Executive Branch* & $+3 /-3$ & $+3 /-3$ & $+3 /-3$ & $+2 /-2$ & $+1 /-1$ & $+2 /-2$ & $+2 /-2$ & $+1 /-1$ \\
\hline
\end{tabular}

Initial Allotment: All participants begin the simulation with a 10-vote baseline.

Political Party: All participants will either gain or lose votes for the extent to which the final bill supports the legislative agenda of their respective political party. The allocation of these votes is at the full discretion of the instructor, and may be anywhere within the range of possible points. For example, if a the final bill was ultimately in favor of the Republican Party, but a Democratic senator was able to attach several debilitating amendments, this senator might lose only 6 votes instead of the possible 10. Also, House representatives are held more accountable by this category than senators because senators have a longer term of office and longer voting record with which to support their respective party.

Party Leadership: Those participants representing party leadership are held more responsible than mere representatives for the final outcome of the bill given their extensive public exposure.

State Constituents: All participants must take into account the interests of their constituents on the issue at hand, and will either gain or lose votes for the extent to which the final bill benefits the constituency of their states. In this category. House representatives are held more accountable to their constituents given their more frequent reelections.

Interest Groups: The various interest groups participating in the simulation will target the appropriate participants to seek their support. Leadership roles and key states are targeted more heavily than others. Likewise, senators are targeted more than House representatives because of their extensive public exposure and greater influence.

Executive Branch: Appropriate participants will be targeted by the executive branch for their support. As with interest groups, leadership roles and key states are targeted more heavily than others.

*Individuals representing interest groups and the executive branch are given a finite number of votes to be distributed across the simulation. The numbers represented here only indicate the maximum number of votes that can be given to any individual by these parties.

(continued) 


\section{APPENDIX (continued)}

\section{SAMPLE STUDENT A: MAJORITY LEADER IN THE SENATE, IL (D) ISSUE: OIL DRILLING IN ANWR}

This student began the simulation with 10 votes. The final bill passed at the end of the simulation was supported by the Democratic Party, but Republican opposition had managed to pass several amendments undercutting key provisions of the Democratic bill, and so this student was only awarded six votes by the political party to reflect this success. As majority leader, this student received another two votes for successfully leading the Democratic senators to support the final bill (they did not receive the possible three votes because of the amendments passed by Republican opposition). This student represented the constituents of Illinois; though in Illinois this issue was not a direct prioritythe majority of constituents supported a liberal legislative agenda. For adequately representing the constituents this student received four votes. This student was targeted by an environmental interest group during the simulation and accepted two votes to support an environmentally friendly final bill. As majority leader, this student was also targeted by the Republican executive branch, and lost two votes for refusing to support a bill more in line with the Republican executive's agenda. Therefore, at the end of the simulation, this student had garnered 22 votes.

\begin{tabular}{lccccccr} 
STUDENT A & $\begin{array}{c}\text { INITIAL } \\
\text { ALLOTMENT }\end{array}$ & $\begin{array}{c}\text { POLITICAL } \\
\text { PARTY }\end{array}$ & $\begin{array}{c}\text { PARTY } \\
\text { LEADERSHIP }\end{array}$ & $\begin{array}{c}\text { STATE } \\
\text { CONSTITUENTS }\end{array}$ & $\begin{array}{c}\text { INTEREST } \\
\text { GROUPS }\end{array}$ & $\begin{array}{c}\text { EXECUTIVE } \\
\text { BRANCH }\end{array}$ & TOTAL \\
\hline Senate Majority Leader, IL (D) & 10 & +6 & +2 & +4 & +2 & -2 & 22 votes \\
\hline
\end{tabular}

\section{SAMPLE STUDENT B: HOUSE REPRESENTATIVE, CA (R) ISSUE: OIL DRILLING IN ANWR}

This student likewise began the simulation with 10 votes. The final bill passed at the end of the simulation was not supported by the Republican Party, but Republican opposition managed to pass several amendments undercutting key provisions of the Democratic bill. This student chose to vote in favor of the final bill, going against the Republican Party, and lost 8 votes for this decision (but did not lose the possible 10 votes because the student worked to pass one of the Republican Party-sponsored amendments to the final bill). However, the state represented was California, a very liberal state greatly affected by environmental issues, the student gained seven votes for representing the interests of their constituents. This student was targeted by an environmental interest group and accepted two votes in exchange for supporting an environmentally friendly bill. The student lost one vote, however, because the Republican executive branch was very displeased that this representative went against the Republican Party on this issue. Therefore, at the end of the simulation, this student had garnered 12 votes.

\begin{tabular}{lccccccr} 
STUDENT B & $\begin{array}{c}\text { INITIAL } \\
\text { ALLOTMENT }\end{array}$ & $\begin{array}{c}\text { POLITICAL } \\
\text { PARTY }\end{array}$ & $\begin{array}{c}\text { PARTY } \\
\text { LEADERSHIP }\end{array}$ & $\begin{array}{c}\text { STATE } \\
\text { CONSTITUENTS }\end{array}$ & $\begin{array}{c}\text { INTEREST } \\
\text { GROUPS }\end{array}$ & $\begin{array}{c}\text { EXECUTIVE } \\
\text { BRANCH }\end{array}$ & TOTAL \\
\hline House Representative, CA $(\mathrm{R})$ & 10 & -8 & N/A & +7 & +2 & -1 & 12 votes \\
\hline
\end{tabular}

